\title{
ЕВРАЗИЙСКОЕ ПРАВО: ВОПРОСЫ КОНЦЕПТУАЛЬНОГО РАЗВИТИЯ
}

\begin{abstract}
Аннотация: В условиях изменения однополярного мира интеграџионные процессы, которые определяют весь процесс глобализаџии и регионализации, приобретают особое значение. При этом именно регионализация, а не глобализация может привести ксозданию многополярного мира. Наоснове историческогометодапознания автор приходит квыводу, что региональныеобъединения существовалинапротяжении всего периода существования человечества, интеграционные процессы являются неотъемлемой частью эволюиии. Региональная интеграчия представляет собой довольно сложное синергетическое явление, автором проанализированы понятие, виды и классификации региональной интеграчии, существующие в доктрине, сформулирована классификация интеграчионных процессов в правовой сфере. На современном этапе, с учетом развития интеграционных процессов на евразийском пространстве, создания Евразийского экономического союза, неизбежно формируется евразийское право, как составная часть международного регионального права. В статье сформулировань понятие, предмет, источники, методы, приниипымеждународного регионального права какотраслимеждународного права; рассмотрень институциональные и павовые особенности евразийской интеграции, обоснованы формирование евразийской отрасли законодательства и процессы формирования евразийского права как подотрасли международного права и как научной и учебной дисчиплины.

Abstract: Under the conditions of changing of the unipolar world integrative processes that define the whole process of globalization and regionalization attain a special meaning. At the same time, it is the regionalization and not the globalization that can lead to the establishment of the multipolar world. Based on the historical method of cognition, the author comes to a conclusion that regional communities existed across the whole period of the existence of mankind, and the integrative processes became the intrinsic part of the evolution. Regional integration represents a quite complicated synergetic phenomenon; the author analyzes the concept, types, and classifications of the regional integration, which are stated in the doctrine; classification of the integrative processes within the legislation is being formulated. At the current stage, taking into consideration the integrative processes within the Eurasian region and the creation of the Eurasian Economic Union, forming of the Eurasian law is an inevitable component of the international regional law. This article structures the concept, subject, sources, methods, and principles of the international regional law as a branch of international law; it also reviews the institutionalized and legislative aspects of the Eurasian integration, and substantiates the forming of the Eurasian branch of the legislation and the processes of forming the Eurasian law as sub-branch of international law and scientific and educational disciplines.
\end{abstract}

Ключевые слова: Евразийское право, интеграция, регионализаџия, глобализация, система права, правовая интеграџия, экономическая интеграция, социальная интеграџия, военно-политическая интегращия, евразийский союз.

Keywords: Eurasian law, integration, regionalization, globalization, legislative system, legislative integration, economic integration, social integration, military- political integration, Eurasian Economic Union.

\section{Актуальность}

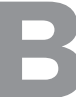
опросы мировой глобализации, регионализации и интеграции на сегодняшний день становятся все более актуальными. Перед государствами в определенных регионах, в том числе и в Евразии, стоят схожие проблемы, решение которых возможно только путем объединения усилий всех соседствующих стран посредством применения единых методов, при этом основным критерием выбора таких методов является «всеобъемлющий принцип эффективности»[1].

В основе региональной интеграции лежат интеграционные процессы в региональном масштабе, а наряду с термином «интеграция» очень часто используются понятия «глобализация» и «регионализация», в связи с чем принципиальное значение имеет соотношение этих понятий. Здесь можно отметить, что в современном мире эти понятия являются наиболее распространенными и в то же время дискуссионными понятиями, что в первую очередь, обусловлено их относительной новизной, не вполне определенной правовой природой, а также отсутствием четкого понимания их реальных процессов.

Основой интеграции, как писал норвежский исследователь Б. Хеттне, является наличие объективных факторов сплочения как в социальной сфере - к примеру, этнический состав, религия, осознание общей истории, так и в экономической или политической областях - торговля, инвестиции или идеология[2].

Интеграция может осуществляться как на региональном, так и на универсальном уровне. Можно считать, что инте- грация на универсальном уровне может именоваться глобализацией. Хотя в геополитическом смысле глобализация достаточно часто воспринимается как американская политика.

Основу понятия «регионализация» составляет термин «регион», который происходит от латинского глагола «regere» - править или командовать. По мнению Н.И. Лапина, «регион - это исторически сложившееся социокультурное сообщество, в котором первичные поселенческие общности и индивиды, создающие свои жизненные миры, непосредственно взаимодействуют со структурами большого общества - социальными институтами, организациями»[3]. В отношении регионализации не все авторы единодушны в определении момента возникновения данного явления. Например, ряд исследователей склонны считать, что изначально во времени получили распространение процессы глобализации, а процессы регионализации вызваны распадом биполярного мира.

При таком понимании можно сделать вывод о том, что интеграция отражает в целом все процессы как глобализации, так и регионализации является их отличительным признаком, их неотъемлемой частью. Они соотносятся как причина и следствие, поскольку прочессы глобализаџии и регионализации ведут к интеграџии государств.

\section{Исторические аспекты}

Однако было бы неверным говорить о глобализации и регионализации как о явлениях, характерных исключительно для современного мира. Эти процессы происходили на протяжении 
DOI: $10.7256 / 1811-9018.2014 .12 .14003$

При цитировании этой статьи сноска на dоі обязательна

\section{Право и политика $12(180) \cdot 2014$}

всего периода существования межгосударственного устройства. В древнем мире существовала Римская империя. В период средневековья были образованы Франкское государство, в период своего расцвета занимавшее большую часть Европы, Византийская империя и Арабский халифат. Новое время характеризовалось увеличением активности региональных процессов между государствами. Известны Кальмарская (1397-1523) и Иберийская (1580-1640) унии, конфедерации Соединенных Штатов Америки (1776-1777 годы и 1788-1789 годы), Швейцарский (1291-1848) и Германский союзы (1815-1866) и т.д.

Исключением не является и евразийский регион, где постоянно функционировали региональные объединения. Великий скифский союз, Золотая Орда, Российская империя, Советский Союз, Совет экономической взаимопомощи (СЭВ), Организация Варшавского договора - это только некоторые исторические примеры евразийской регионализации.

Наращивание различных форм региональных проектов стало с конца 1990-х годов отмечаться практически во всем мире. Это взаимодействие государств в рамках Евро-Атлантического региона, функционирование Североамериканской зоны свободной торговли (НАФТА) и Союза южноамериканских наций (УНАСУР) в Америке, деятельность Лиги арабских государств (идеи арабского единства) и Африканского союза, планы по создании Южнотихоокеанского союза в Австралии и Океании, интеграционные процессы в Восточной (Восточноазиатский союз) и Южной Азии (Южноазиатский союз).

Региональные институты в настоящее время стали включать в себя целый набор новых миссий, охватывая все больше новых сфер, в том числе и такие транснациональные вопросы, которые ранее не входили в их компетенцию, стали как политика, безопасность, экология и культура. В литературе такая всемирная тенденция регионализма (объединения) получила название «нового регионализма», в процессе которого государства - участники не ограничиваются формальными межгосударственными интеграционными объединениями, при этом резко возрастает организаций, действующих в рамках консультативного формата (саммиты, форумы и программы). При этом все чаще говорят об ином значении термина «регион», отказываясь от его географического признака, учитывая его «разброс» по всему миру, распространение на ряд разных регионов.

Эти изменения нельзя игнорировать, их необходимо признавать, изучать и объяснять. Соглашаясь во многом с представителями нового регионализма, представляется, что под регионом следует понимать политические, экономические, сочиальные и иные образования, которые в настоящее время обусловлены не только географическими или социальными факторами, но такжемогут базироваться на функциональном подходе (общие цели и доктрины) и иметь трансграничный характер.

В условиях изменения однополярного мира интеграционные процессы, которые определяют весь процесс регионализаиии, приобретают особое значение. Такие процессы, основанные в основном на историческом опыте взаимодействуюших стран, неизбежны. Если ранее в рамках региональных организаций страны взаимодействовали в основном в экономической или военно-политической сферах, то современные интеграционные процессы охватывают политические, сочиальные, правовые и иные аспекты. Сферы сотрудничества не могут развиваться раздельно, поскольку они неразрывно связаны друг с другом. Невозможно до- стигнуть высоких результатов, к примеру, в социальной интеграции без соответствующего уровня взаимодействия в экономической или правовой сферах.

Представляется, что достижение основной цели интеграционных прочессов - обеспечение прав и свобод человека и повышение благосостояния граждан - возможно только в результате сотрудничества стран одновременно во всех сферах в рамках регионального образования.

При этом именно регионализация, а не глобализация является наиболее эффективной формой развития и может привести к созданию многополярного мира.

На основании изложенного определение региональной интеграции может быть следующим. Региональная интеграиия - сотрудничество стран определенного географического, сочиального или функционального (общность доктрин и целей) региона посредством создания региональных объединений (как институциональных - основанных на договорах и других юридических соглашениях, так и неформальных - действуюших в рамках консультативного формата (саммиты, форумы и программы) в целях развития и укрепления экономических, политических, сочиальных и иных связей, а также достижения единых иелей на основе принципов добровольности, в процессе которого происходит взаимопроникновение национальных интересов, а также сближение различных структур государств.

\section{Виды региональной интеграции}

Поскольку региональная интеграция представляет собой довольно сложное синергетическое явление, в доктрине выделяют множество ее видов.

Однако наиболее целесообразной представляется классификация в зависимости от сфер интеграционных процессов. Так, можно выделить экономическую, военно-политическую и социальную интеграцию.

В таком направлении развивали представления об интеграции М. Вебер и Э. Дюркгейм[4]. Эти ученые впервые заговорили о таких принципиальных аспектах интеграции как социальная, экономическая и политическая интеграция.

Как правило, региональные образования имеют основное (приоритетное) направление сотрудничества, будь то экономическая, социальная или военная - политическая сфера, однако такое взаимодействие стран сопровождается интеграционными процессами в иных сферах общественной жизни. В частности, формирование общего рынка, связанного с предоставлением свободы передвижения рабочей силы, требует соответствующих изменений в социальной сфере - формирование миграционного пространства, решение вопросов социального обеспечения, здравоохранения, равных прав граждан и т.д. При этом, если видам и моделям экономической интеграции в научной литературе посвящено большое количество работ, то на доктринальном уровне социальная и военно-политическая интеграция в отличие от экономической интеграции не получили должного раскрытия.

\section{Экономическая интеграция}

Есть много работ, где авторами представлены различные точки зрения на понимание не только сущности экономической интеграции, а также на ее стадии (фазы) и их последо- 
вательность, которые основаны в основном на классической западноевропейской теории, в соответствии с которой выделяют пять форм экономической интеграции: зона свободной торговли, таможенный союз, общий рынок, экономический и валютный союз, полная интеграция[5].

Вместе с тем, анализируя экономическую интеграцию как одну из сфер интеграционных процессов, не все исследователи рассматривают стадийность экономической интеграции в такой последовательности, более того, выделяют и иные стадии. Развитие экономических процессов в различных регионах имеет свои особенности, что в целом приводит к собственным моделям региональной интеграции.

Признавая существование зоны свободной торговли, таможенного союза и общего рынка, некоторые авторы указывают на зону преференциальной торговли, которая предшествует стадии зоны свободной торговли. По мнению других ученых, после формирования общего рынка следует стадия экономического союза, далее валютного (монетарного) и политического союза[6]. Такое разнообразие альтернативных подходов к построению этапов экономической интеграции связано с отсутствием в различных региональных образований единых (стандартных) этапов экономической интеграции. Региональная экономическая интеграция на евразийском пространстве также имеет свои особенности, не следуя в целом классической европейской модели интеграции. Так, в рамках Союзного государства Беларуси и России основной акцент сделан на развитие сотрудничества в социальной сфере и сфере безопасности, а экономическая интеграция стала развиваться между этими странами в рамках «тройки», включающей и Казахстан. При этом зона свободной торговли между ними функционирует в рамках другого регионального евразийского образования-СНГ. Нельзя согласиться с отнесением политического союза к заключительной стадии экономической интеграции, поскольку политическая интеграция должна включаться в отдельный военно-политический блок, который представляет собой одну из самостоятельных сфер взаимодействия интегрирующихся государств.

Одним из направлений экономической интеграции является взаимодействие государств в финансовой сфере. В доктрине выделяются такие стадии финансовой интеграции как клиринговый союз, платежный союз, банковский союз, валютный союз, фискальный союз и финансовый союз. При этом, следует исходить из того, что стадийное развитие интеграционных процессов в экономике может осуществляться параллельно с интеграцией в финансовой сфере. Участники одного и того же регионального образования в качестве наивысшей степени своей интеграции могут предусмотреть, например, создание валютного союза с введением единой денежной единицы, при этом в рамках экономической интеграции ограничиться образованием единого экономического пространства или таможенного союза. Развитие экономических процессов в различных регионах имеет свои особенности, что в целом приводит к формированию собственных моделей региональной интеграции, обусловленных большим числом факторов: общих исторических аспектов, длительностью сотрудничества объединяющихся государств и их активностью в интеграционных процессах, уровнем экономического развития и экономической стабильности стран - участников региональных объединений, территориальногеографическими и иными особенностями.
Таким образом, стадии экономической интеграции целесообразно упорядочить следующим образом: сотрудничество, зона преференциальной торговли (ЗПТ); зона свободной торговли (ЗСТ); таможенный союз; единое экономическое пространство (ЕЭП); экономический союз. А под региональной экономической интеграџией предлагается понимать сотрудничество государств, направленное на постепенное (поэтапное) объединение финансово-экономических систем в регионе.

\section{Социальная интеграция}

Не вызывает сомнений тот факт, что социальная сфера сотрудничества стран должна быть выделена в отдельный самостоятельный вид региональной интеграции и, безусловно, представляет теоретический интерес.

Анализ целей сотрудничества стран в социальной сфере на региональном уровне показал, что можно выделить следующие стадии социальной интеграции:

1. Сотрудничество. На данной (начальной) стадии социальной интеграции стран в регионах происходит налаживание прямых связей, осуществляется единая политика на национальном уровне посредством разработки и реализации общих программ. Так, исходя из положений ст. 2 Нахичеванского соглашения о создании Совета сотрудничества тюркоязычных государств основными задачами ССТГ являются стремление к всестороннему социальному и культурному развитию; расширение взаимодействия в области науки и техники, образования, здравоохранения, культуры и т.д. Аналогичные цели предусмотрены в учредительных документах таких международных организаций, как Франкофония, Содружество наций, Ибероамериканский совет.

2. Единое социальное пространство (ЕСП). Данная стадия социальной интеграции активно прослеживается в актах Союзного государства, в рамках которых принято большое количество документов, направленных на установление равных прав граждан государств - членов в области трудовой занятости, защиты прав работников, в области оказания медицинских услуг, в области защиты прав потребителей и т.д.

Показателен в данной сфере сотрудничества опыт ACЕАН, в соответствии с концепцией которого[7] к 2015 году должно быть образовано социально-культурное сообщество, ориентированное на построение единого общества, основанного на благосостоянии всех граждан в регионе.

3. Паспортный союз. Формирование паспортного союза подразумевает введение единого паспорта граждан государств (паспорт единого образца), который дает право беспрепятственного перемещения через внутренние границы договаривающихся государств без оформления дополнительных проездных документов.

Форма паспортного союза (Северного паспортного союза) действовала на объединенной территории государств-членов Совета министров Северных стран (СМСС, Северного союза) с конца 1950-х годов прошлого века, однако он утратил свое значение с присоединением стран - участников СМСС в 1996 году к Шенгенскому соглашению. Одним из примеров достижения данного уровня социальной интеграции является Экономическое и валютное сообщество стран Центральной 
DOI: $10.7256 / 1811-9018.2014 .12 .14003$

При цитировании этой статьи сноска на doi обязательна

\section{Право и политика $12(180) \cdot 2014$}

Африки (СЕМАК), Карибское Сообщество (КАРИКОМ), где единый паспорт был введен с 1 января 2005 года.

4. Социальный союз, предусматривающий введение единого гражданства, как высшая стадия социальной интеграции. Введение единого гражданства подразумевает равные права и обязанности на всей территории регионального образования во всех областях социальной сферы, что, несомненно, расширяет возможности всех граждан в регионе. Показательным примером в этом смысле является Европейский Союз.

На основании изложенного под региональной социиальной интеграцией предлагается понимать сотрудничество государств, направленное на постепенное (поэтапное) сближение или объединение социиальных систем в регионе.

\section{Военно-политическая интеграция}

Военно-политическая интеграџия предполагает делегирование полномочий по вопросам войны и мира на наднациональный уровень, выработку общих принципов поведения на международной арене в поисках союзников в оборонной сфере, четкие этапы военного строительства, ориентированные в конечном итоге на создание единого оборонного пространства[8].

Учредительные документы различных региональных объединений позволяет выделить следующие стадии военнополитической интеграции:

1. Сотрудничество. Это начальный этап, в рамках которого устанавливаются прямые институциональные связи между соответствующими органами в различных областях военно-политической интеграции.

На данном этапе может быть предусмотрено сотрудничество в области оборонной политики и охраны внешних границ, борьбы с организованной преступностью, сотрудничество в сфере внешней политики по вопросам, представляющим взаимный интерес или осуществление скоординированной внешнеполитической деятельности. Подобные цели предусмотрены в уставных документах большинства региональных организаций, такие как СНГ, ОАГ и др.

2. Единое военно-политическое пространство (ЕВПП) характеризуется более высоким уровнем военно-политической интеграции. На данном этапе интегрирующиеся государства могут образовать общие вооруженные силы, проводят согласованную внешнюю политику и политику в области обороны и обеспечения безопасности, а также осуществляют на коллективной основе защиту территориальной целостности и суверенитета государств - членов.

Так, в задачи Системы сотрудничества американских BBC (SICOFAA) входит укрепление основ международного сотрудничества на территории Северной и Южной Америки и достижение взаимной поддержки путем совместных действий в военно-политической сфере. В соответствии с Договором об учреждении Тихоокеанского пакта безопасности (АНЗЮС) стороны противостоят угрозам политической независимости, территориальной целостности или безопасности, стоящим перед любой из стран в Тихом океане.

Данный уровень интеграции достигнут странами в рамках Североатлантического альянса (НАТО), Союзного государства Беларуси и России (СГ) и Организации Договора о коллективной безопасности (ОДКБ).
3. Единый военно-политический союз (сообщество) как наивысшая стадия военно-политической интеграции. Существующие акты региональных организаций предусматривают образование подобного союза. Можно предположить, что наравне с уже образованными общими коалиционными группировками войск должно быть проведено полное расформирование национальных вооруженных сил государств - членов региональной организации с одновременной передачей всех военно-политических полномочий с национального уровня специальным органам региональной организации в целях централизованного обеспечения безопасности в регионе и осуществления внешней политики объединяющихся государств.

Таким образом, под региональной военно-политической интеграцией предлагается понимать сотрудничество государств, направленное на постепенное (поэтапное) сближение или объединение военно-политических систем в регионе.

\section{Правовые основы региональной интеграции}

Учитывая глубокие исторические корни интеграционных процессов, не удивительно, что вопросы региональной интеграции уже давно находятся «в поле зрения» экономистов[9], социологов[10], политологов[11], историков[12] и философов[13].

Вместе с тем изучение и анализ региональной интеграции необходим также и с правовой позиции, поскольку в основе любого взаимодействия государств на межнациональном уровне, в том числе и в рамках региональных организаций, лежит право.

Именно право определяет статус и сферу деятельности главных действующих лиц в условиях интеграции, контролирует, а при необходимости и ограничивает их действия, выполняет роль своеобразного нормативного регулятора во взаимоотношениях между участниками интеграционного процесса[14], реализует функцию «упорядочения и стимулирования интеграционного процесса, консолидации его содержательных и организационных структур»[15].

Взаимодействие на региональном уровне требует от государств принятия различных правовых актов, которые могут носить для стран - участниц как рекомендательный, так и обязательный характер, что влечет за собой формирование международных региональных норм. Именно поэтому в уставных актах большинства региональных организаций стороны указывают на правовое сотрудничество, при котором могут быть использованы самые различные механизмы: рецепция, гармонизация, унификация и стандартизация[16].

Вместе с тем в ряде региональных образований интеграционные процессы достигают такого уровня, что можно говорить о формировании единого правового пространства, которое характеризуется единством правового регулирования социальных, экономических, внешнеполитических и иных отношений в регионе. Иными словами, сферой правового регулирования общественных отношений является объединенная территория всех государств в рамках конкретного регионального образования. Более того, в процессе интеграции с переходом к высшим ее стадиям региональные нормы трансформируются в национальное право объединяющихся государств.

Первопричины интеграционных процессов, их источники, особенности и правовые аспекты активно обсуждаются и среди правоведов[17]. 
Не умаляя значительного вклада отечественных правоведов в изучение интеграционных процессов, отметим, что эти работы в основном направлены на анализ правовых аспектов взаимодействия стран, входящих в конкретные региональные образования (ЕС, СНГ, ЕврАзЭС и т.д.).

Однако без выявления специфических правовых особенностей интеграции государств в иелом невозможно выявить, понять и объяснить закономерности таких процессов, тем более, делать какие-либо прогнозы в развитии взаимоотномений интегрирующихся стран. Право, регулирующее общественные отношения, только тогда может привести к образованию единого правового общества, когда оно эффективно.

\section{Международное региональное право как отрасль МП: вопросы теории и практики.}

C возникновением новых отношений, которые требуют соответствующей регламентации, система права постоянно пополняется новыми отраслями и подотраслями права, его институтами и нормами, что в целом делает ее более эффективной. В современных условиях регионализации наблюдается тенденция формирования региональных правовых комплексов как в Евразии, так и в ряде других регионов Европе, в Америке, в Африке, в Азии, Австралии и Океании. В связи с этим, процесс изучения евразийского права необходим в составе более крупного блока, каким должно являться международное региональное право.

\section{Понятие и предмет международного регионального права}

Предложенное название не случайно. В доктрине раннее уже высказывались мнения о процессах формирования так называемого «интеграиионного права», «права региональной интеграции», а такжепозиции, в соответствии с которой в рамках международного права выделялось региональное международное право[18] или так называемые региональные международные правовые комплексы.

Мы намеренно использовали термин «региональное», поскольку оно является ключевым в описании тех процессов, которые лежат в основе предмета международного регионального права, в свою очередь понятие «интеграция» выступает в качестве отличительного признака всего процесса регионализации, а во-вторых, большинство западных и ряд отечественных ученых под интеграцией понимают процессы, происходящие только в рамках Европейского союза. Использование понятия «международное» в названии регионального права обусловлено двумя причинами: с одной стороны, по аналогии с названиями отраслей международного права, поскольку региональное право является составной частью международного права, с другой стороны, без указания на международный характер регионального права могут возникнуть ассоциации с «регионами» в рамках федеративных государств, к числу которых относится и Россия.

\section{Предмет международного регионального права}

Можно утверждать, что международное региональное право является уникальной особой частью международного права, так как включает в себя, в зависимости от регионов, черты различных правовых систем.
Специфичен и предмет регионального права, который представляет собой достаточно сложную структуру отношений.

Первый уровень отношений составляют отношения государств по формированию (учреждению) регионального образования и его ликвидации (роспуску).

На мировом уровне функционирует более ста тридцати региональных образований, которые различны по степени (глубине) интеграции, сферам взаимодействия, по наличию институциональных органов и т.д., что требует обособленного правового регулирования. Такие отношения обладают определенной спецификой, отличной от отношений, составляющих предмет права международных организаций. Когда страны ведут переговоры относительно учреждения (создания) регионального образования, они намерены решать общие проблемы опосредованно, через создаваемое региональное образование.

Вторую группу отношений составляют отношения уже созданных региональных образований с государствами -его участниками.

Такие отношения отличаются разнообразием внутри каждого конкретного объединения и обладают присущей именно им спецификой с учетом норм, принимаемых на уровне регионального образования.

Юридическая сила норм, принимаемых на региональном уровне, различна и определяется учредительными документами самого регионального образования.

Третья группа отношений - это отношения государств -членов между собой в предусмотренных учредительными документами сферах взаимодействия (экономической, социальной, военно-политической), регулируемые как частными, так и публичными отраслями и институтами. Отношения этих же стран между собой в иных сферах общественной жизни (не предусмотренное в рамках региональных образований) должны регулироваться иными отраслями международного права. Такие отношения могут быть осложнены собственными нормами регионального объединения, а также правилами двух- и многосторонних соглашений, которые заключаются в рамках регионального объединения для достижения поставленных перед сторонами целей.

К четвертой группе отношений, регулируемых региональным правом, необходимо отнести взаимоотношения институциональных структур в рамках конкретного регионального объединения.

Таким образом, отношения, регулируемые международным региональным правом, образуют четыре самостоятельные группь, которые обладают определенной спецификой и позволяют выделить его в отдельный структурный элемент международного права.

На основании изложенного предлагается следующее определение регионального права. Международное региональное право - это отрасль международного права, регулирующая комплекс общественных отношений государств по созданию и ликвидации региональных организаций, взаимодействию региональных организаций с их членами, по сотрудничеству государств между собой в рамках региональных организачий в различных сферах, обусловленных целями региональных организаций, а также взаимодействию региональных институциональных структур в рамках конкретного объединения. При этом необходимо исходить из того, что данная отрасль права носит комплексный характер, что обусловлено ее предметом. 
DOI: $10.7256 / 1811-9018.2014 .12 .14003$

При цитировании этой статьи сноска на dоі обязательна

\section{Право и политика $12(180) \cdot 2014$}

\section{Методы международного регионального права}

Региональному праву присущи используемые в международном и национальном праве основные методы (диспозитивный и императивный). Здесь следует указать, что в доктрине нет единого мнения относительно методов правового регулирования, используемых в международном праве. В международном публичном праве, несомненно, имеет место публично-правовое регулирование, которое, на наш взгляд, отличается определенной спецификой. Применение императивного метода, который в большей степени характерен для публичного права, в современном международном праве противоречит сущности последнего. Отношения между государствами должны строиться на началах равенства, а не на началах власти и подчинения. Таким образом, специфика публично-правового регулирования в МП заключается в том, что публично-правовой аспект может иметь место и тогда, когда отношения между субъектами строятся на началах равенства.

Специфика методов, используемых в международном региональном праве, заключается в том, что им в большей степени присуща централизация, что обусловлено спецификой взаимодействия государств в рамках регионального интеграционного объединения. На правообразование, а соответственно, и на выбор приоритетного метода правового регулирования (их совокупности) в рамках каждого отдельного регионального образования влияет несколько факторов. К их числу следует отнести, в первую очередь, специфику отношений, регулируемых региональным правом. В частности, в отношениях государств по созданию регионального образования приоритетным выступает диспозитивный метод регулирования, предполагающий равенство сторон. Выбор же основного метода правового регулирования отношений между региональным образованием и его членами зависит от полномочий структурных органов регионального образования, т.е. решение этого вопроса производно и зависит от самих членов регионального образования.

\section{Источники международного регионального права}

Источники регионального права подразделяются на источники первичного права регионального интеграционного объединения и на источники вторичного (производного) права.

Первичное право регионального образования составляют документы, носящие основополагающий характер. В первую очередь, к источникам первичного права следует отнести учредительные документы (договоры, акты, декларации, положения), ревизионные договоры, посредством которых вносятся поправки в учредительные документы, а также в ряде региональных организаций договоры о присоединении (о вступлении) новых государств. В большинстве случаев к таким актам (соглашениям) прилагаются многочисленные протоколы (они могут устанавливать особые изменения или дополнения к правовому статусу вступающих государств), которые также являются их составной частью.

В свою очередь, к источникам вторичного международного регионального права относятся правовые акты, которые принимаются уполномоченными органами регионального объединения.
Процедуры принятия такого рода правовых актов регламентированы нормами первичного права и не единообразны в различных интеграционных образованиях.

В частности, в ЕС применяются различные способы голосования: как единогласно, так и квалифицированным большинством, причем каждое государство-член ЕС имеет число голосов, зафиксированное в договоре. Однако принципу «большинства голосов» отдается большее предпочтение, что значительно упрощает принятие решений по тем или иным вопросам.

Иная ситуация предусмотрена в договоре стран СНГ «О создании Экономического союза», в соответствии с которым решения уполномоченных органов СНГ, которыми выступают Совет глав государств и Совет глав правительств, по вопросам функционирования экономического союза принимаются с общего согласия, т.е. консенсусом.

Для некоторых региональных образований характерен так называемый комбинированный порядок голосования. Например, в одном из крупнейших региональном образовании - Африканском союзе - решения Исполнительного совета $\mathrm{AC}$ принимаются на основе консенсуса или $2 / 3$ голосами государств-членов АС. При этом решения по процессуальным вопросам принимаются простым большинством голосов.

В сравнении с первичным правом, вторичное региональное право имеет гораздо больше материальных источников, что обусловлено характером деятельности региональных интеграционных образований, направленной на достижение поставленных целей[19].

Несмотря на приоритет первичного права над нормами вторичного права, последние в правовой системе международного регионального права наиболее динамичны, поскольку именно посредством принятия актов вторичного права региональные интеграционные организации осуществляют регулирование отношений по всем вопросам, отнесенным к компетенции их органов.

\section{Принципы международного регионального права}

Региональное право построено на системе принципов, в основе которых лежат общие принципы международного права, а некоторые принципы имеют оригинальную природу.

Общие принципы международного права могут быть закреплены непосредственно в документах регионального образования. Например, в 1990-е годы в Договор о Европейском союзе включен ряд основополагающих правовых принципов: принципы свободы, демократии, уважения прав человека и основных свобод и принцип правового государства. В ст. 3 Устава СНГ содержатся такие принципы как уважение суверенитета государств - членов, нерушимость государственных границ, верховенство международного права в межгосударственных отношениях и др.

Собственные принципы регионального права как отрасли международного права можно сгруппировать на специальные отраслевые и специальные институционные принципы.

К специальным отраслевым принципам регионального права следует отнести принципы, которые отражают специфику регионального права как отрасли международного права. В числе таких принципов следует назвать: принцип целесообразности и обоснованности создания новой регионального объединения; обеспечение взаимной заин- 
тересованности участников регионального объединения; добровольность вхождения субъекта международного права в региональную структуру; принцип разноуровневой и разноскоростной интеграции и т.д.

Специальные институционные принципы регионального права составляют общие начала, которые лежат в основе того или иного регионального образования. Например, исходя из ст. 4 Учредительного акта Африканского союза можно выделить следующие специальные институционные принципы: взаимозависимость государств-членов союза; участие африканских народов в деятельности союза; формирование общей оборонной политики африканского континента; право союза на вмешательство в дела государств по решению Ассамблеи при совершении военных преступлений и преступлений против человечества; гендерное равенство.

\section{Систематизация и структуризация международного регионального права}

При этом систематизация и структуризация международного регионального права представляет собой внутреннюю структуру права такого огромного комплекса, что вызывает определенные сложности в формировании элементов регионального права.

Проблемы при структуризации опосредованы различным уровнем интеграции сотрудничающих государств в рамках тех или иных региональных образований, разнообразной внутренней структурой каждой региональной организации, существенными различиями в порядке принятия решений и юридической силе таких решений, а также многими иными факторами.

Кроме того, несмотря на более чем столетнюю историю некоторых региональных организаций, можно говорить о том, что такие образования и на сегодняшний день находятся в процессе активного развития. Так, Южноафриканский Таможенный союз (ЮАТС) 1889 года считается самым старым таможенным союзом в мире. 29 июня 1910 года было принято Соглашение ЮАТС, которое вступило в силу с 1 июля 1910 года и действовало вплоть до 1969 года. Несмотря на достигнутые значительные достижения сторон в рамках Соглашения 1910 года нельзя сказать, что Союз полностью достиг поставленных перед ним целей. Пересмотренное Соглашение от 2002 года, в котором были поставлены новые задачи, было подписано сторонами с учетом сложившихся реалий мировой регионализации и глобализации., соответственно формируется новая правовая база ЮАТС.

Говоря о формировании в системе международного права регионального права, необходимо также учитывать, что, как и любая иная система, ее внутренние элементы должны быть согласованы и находиться в постоянной взаимосвязи. Именно поэтому на данной стадии формирования регионального права можно говорить исключительно о становлении и развитии искомых критериев его систематизации и структурирования.

В соответствии с принятой структуризацией международного права, а также по аналогии со структуризацией национального права, в рамках регионального права следует выделить подотрасли и институты.

В целях действенной (универсальной) систематизации и структуризации регионального международного права на подотрасли в качестве системообразующего критерия целесообразно использовать региональный признак. Как по- казывает практика регионализации, в региональные группы страны объединяются как по территориальному и социальному (общие культурно-исторические и политико-правовые традиции), так и по функциональному принципу (общность доктрин и целей). Перед такими странами, как правило, стоят схожие проблемы, решение которых требует совместных усилий. Классическими примерами таких региональных организаций являются Евросоюз, Африканский союз и т.д.

Еще один довод в пользу выбранного критерия заключается в том, что государства одного условного региона, как правило, являются участниками (членами) иных субрегиональных организаций, которые, в свою очередь, большей частью функционируют в пределах того же региона, что оказывает влияние на их систему права.

Кроме того в уже сложившихся регионах в большинстве случаях действует специфическая система права. В Европе и Северной Америке параллельно функционируют континентальная и англо-саксонская системы права. Унификация правовых систем в Латинской Америке осуществлялась на основе на основе индейского и континентального права. На африканском континенте основу права каждого африканского государства образуют местные обычаи, а также правовые нормы господствующей страны - колонизатора. Значительной спецификой обладает также мусульманское и индусское право.

С учетом проводимой в рамках региональных образований унификации и стандартизации национальных систем права, именно региональный признак с позиции формирования институтов регионального международного права представляется наиболее удачным. Кроме того, использование регионального признака в качестве критерия для выделения институтов регионального международного права позволит в дальнейшем выявить определенные закономерности в интеграционных процессах в крупных регионах. Исходя из такого подхода к делению международного регионального права на подотрасли, можно выделить: Евразийское право; Европейское право; региональное право Азии, региональное право Австралии и Океании; Африканское право; Американское право и межрегиональное право, регулирующее взаимоотношения стран, имеющих общие цели (внешнеполитические или внешнеэкономические доктрины), но находящихся на различных континентах.

Поскольку критерий деления международного регионального права на подотрасли отличает достаточно общий и условный признак регионального деления, следует учитывать, что в рамках каждого континента действует определенное количество конкретных субрегиональных организаций, со своими собственными целями, организационной структурой, численным составом их участников и иными особенностями. Каждое субрегиональное объединение имеет собственную правовую базу, на основании которой решаются все организационные и иные вопросы. Таким образом, в качестве критерия деления международного регионального права на институты предлагается использовать критерий «субрегиона», иными словами институты международного регионального права составляют системы права каждого отдельного регионального объединения.

Например, в европейском региональном праве можно назвать такие институты как право Совета Европы, право Евросоюза, право Северного совета и т.д. В региональном праве стран Африки следует выделить в качестве институ- 
DOI: 10.7256/1811-9018.2014.12.14003

При цитировании этой статьи сноска на doi обязательна

\section{Право и политика $12(180) \cdot 2014$}

тов право Африканского союза, право Южноафриканского сообщества развития (САДК), право Организации общего рынка Восточной и Южной Африки (КОМЕСА) и т.д.

В структуру институтов евразийского права может входить право таких организаций как Содружество Независимых государств (СНГ); Союзное государство Беларуси и России (СГ); Евразийское экономический союз (ЕАЭС); Организация договора о коллективной безопасности (ОДКБ); Шанхайская организация сотрудничества (ШОС) и т.д.

\section{Евразийское право как подотрасль МП}

В начале XX века британский ученый X. Маккиндер стал инициатором так называемой теории евразийской «опорной территории», а в дальнейшем теории «сердца Центральной и Восточной Европы», в основе которой лежит идея о евразийском пространстве как центре мира[20].

Теория евразийства активно развивалась в начале XX века и в среде российских эмигрантов[21]. Цель данной концепции заключалась в создании новой русской идеологии, при этом объединяющим фактором была идея того, что Россия является центром Евразии, связующим страны Западной Европы и Азии.

Значительный вклад в развитие концепции евразийства внес Лев Гумилев, который рассматривает Евразию как олицетворение социогеографического пространства и особого этнокультурного мира. Его концепция во многом проясняет удачи и неудачи действующих региональных организаций. По его утверждению, не все определяется экономическими или политическими предпосылками. Для успешной интеграции необходимо еще одно непременное условие - идейное, духовное начало, когда к интеграции готовы не только экономика и политика, но и народы[22]. При этом историкокультурная самобытность Евразии, объединение в единое политико-культурное пространство позволяет говорить о единой самоидентификации евразийских этносов.

\section{Институциональные и правовые особенности евразийской интеграции}

Распад СССР в 1991 году стал одним из значимых политических событий на мировой арене, что привело к образованию на его основе 15 независимых государств, что неизбежно повлекло за собой необходимость установления новых механизмов взаимодействия в различных сферах общественной жизни, которые бы соответствовали геополитическим реалиям на данном историческом этапе. В итоге 8 декабря 1991 года было подписано Соглашение о создании Содружества Независимых Государств. Хотя поставленные цели в рамках СНГ не были полностью достигнуты, его образование сыграло определенную роль в дальнейших интеграционных процессах на евразийском пространстве, не позволив окончательно разрушить экономические связи вновь образованных государств и послужив основой их дальнейшего взаимодействия.

Хотелось бы выделить особенности евразийской интеграции.

Одна из них заключается в том, что интеграционные процессы на евразийском пространстве протекают значительно быстрее, чем в иных регионах[23], что обусловлено, в первую очередь, общим историческим прошлым бывших советских республик: общее культурное наследие, отсутствие языковых барьеров, смешанные браки и т.д. являются, несомненно, важными факторами, стимулирующими взаимодействие государств на евразийском пространстве. Академик В.С. Степин справедливо отмечает, что учет исторического и культурного контекста является важнейшей проблемой, без осознания которой невозможно получить практически действенных и успешных решений[24].

Вторая особенность заключается в том, что на евразийском пространстве образовано и действует более 15 региональных структур, которые условно можно разделить на четыре группы, характеризующиеся разноуровневой, разноскоростной и разновекторной интеграцией:

1) организации, составляющие основу евразийской интеграции, в которых ведущую роль играет РФ (СНГ, ЕАЭС, СГ, ОДКБ);

2) организации, в которых Россия делит лидерство с другими странами: Шанхайская организация сотрудничества (ШОС), куда помимо постсоветских республик вошел Китай, Организация черноморского экономического сотрудничества (ОЧЭС), Саммит каспийских государств (Россия, Казахстан, Туркменистан, Иран, Азербайджан); саммиты СВМДА (Совет по взаимодействию и мерам доверия в Азии), БРИКС и РИК (Россия, Индия, Китай);

3) региональные интеграционные организации (без участия РФ), образуемые в целях достижения большей независимости от Российской Федерации и желании играть «ведущую роль» на постсоветском пространстве, основной курс которых направлен на интеграционные процессы со странами ЕС и США (Содружество демократического выбора (СДВ), Организация за демократию и экономическое развитие (ГУАМ)).

4) в отдельную группу следует объединить такие организации, как Организация экономического сотрудничества (ОЭС), Совет сотрудничества тюркских государств (ССТГ, Тюркский совет), Союз персоязычных государств (СПГ), в состав которых вошли страны по территориально-этническому признаку. Три персоязычных государства (Иран, Таджикистан, Афганистан) сотрудничают в рамках СПГ, а в состав Тюркского совета входят Киргизия, Азербайджан, Казахстан, Турция. При этом в рамках ОЭС, объединяющей в основном государства с преобладающим тюркоязычным и персоязычным населением кроме Ирана, Афганистана, Турции и Пакистана, вошли шесть постсоветских республик: Туркмения, Таджикистан, Узбекистан, Казахстан, Азербайджан и Киргизия. Отдельно функционирует такая организация как Содружество непризнанных государств (СНГ-2) и региональные программы ЦАРЭС и СПЕКА.

Третьей характерной особенностью протекающих на евразийском пространстве интеграционных процессов является также то, что достигая значительных успехов в одних сферах и областях общественной жизни в рамках одного регионального образования, страны - участницы компенсируют ослабление интеграционных процессов в иных сферах посредством значимых достижений в рамках иных региональных образований. Так, члены Союзного государства достигли значительных успехов в социальной сфере, а экономическая сфера стала основным аспектом взаимодействия в рамках ЕврАзЭС, при этом сотрудничество в военно-политической сфере активно развивается в рамках как Союзного государства, так и ОДКБ. 
Таким образом, региональные процессы на евразийском пространстве приобретают все более сложные взаимозависимые формы. Несмотря на значительные трудности в реализачии интеграционных планов на постсоветском пространстве, эксперты позитивно оченивают достигнутые результаты, а также ожидаемый эффект от проведения запланированных интеграционных мероприятий[25]. Евразийская интеграчия должна стать альтернативным глобализации путем развития и одним из полюсов современного мира[26].

\section{Формирование евразийского права как научной и учебной дисциплины}

Процессы формирования региональных правовых комплексов наблюдаются в настоящее время во многих регионах мира. Право Европейского союза, к примеру, уже являет собой пример консолидированной отрасли законодательства. В евразийском регионе действует порядка 15 интеграционных структур и саммитов, созданных как с участием РФ, так и без нее. Однако региональные акты тех организаций, в которых Россия выступает полноправным членом, являются частью ее системы законодательства. Как уже отмечалось на объединенной территории государств-участников ЕврАзЭС действует Таможенный кодекс Таможенного союза, который заменил собой соответствующие национальные кодексы. С 1 января 2012 года вступили в силу все основополагающие акты ЕврАзЭС, направленные на формирование Единого экономического пространства, а 29 мая 2014 года в Астане на заседании Высшего Евразийского экономического совета главы России, Белоруссии и Казахстана подписали Договор о Евразийском экономическом союзе, который вступит в силу с 1 января 2015 года.

Более того, исходя из создания Евразийского экономического союза, можно говорить о том, что в системе российского законодательства стал формироваться особый блок как региональных, так и национальных актов, который свидетельствует о начальных процессах становления новой отрасли - евразийской отрасли законодательства.

Представляется, что и в России, и в Евразии необходима консолидация норм, регулирующих сферу евразийской интеграции в единый блок - евразийское право, тем более, что процесс создания и функционирования научных школ, изучающих отдельные аспекты евразийской интеграции в ведущих научных и учебных заведениях налицо. Евразийское право, несомненно, долюно стать одним из приоритетных направлений развития отечественной юридической науки.

Очевидна и потребность в специалистах в рассматриваемой области, что создает предпосылки также для разработки и внедрения в образовательный процесс системы высшего профессионального образования нового учебного блока евразийского права.

Разумеется, было бы крайне недальновидно говорить о наличии проблем как об основании формирования отдельной отрасли права. Несмотря на очевидно постоянный характер и имманентность проблем регионализации и интеграции для современного общества, вполне возможно, что формирование отдельной отрасли права проблем не решит. Вместе с тем региональные интеграционные процессы, происходящие как в Евразии, так и в других регионах мира, в правовой сфере требуют уже не прикладных, инструментальных, функциональных или иных аналогичных аспектов, а расширения границ правопонимания данного явления. С учетом современных процессов глобализации и регионализации хотелось бы также подчеркнуть важность научных исследований, посвященных изучению положительного зарубежного опыта.

Изложенное дает основание утверждать, что теоретические аспекты евразийского права как составной части международного регионального права должны быть отнесены к числу наиболее актуальных современных проблем юридической науки, заслуживающих самостоятельного изучения и развития.

\section{Немного геополитики}

Необходимо отметить, что обострение международной обстановки, украинский кризис, санкции стран евроатлантического альянса, накал политических страстей, о чем говорил С.Е.Нарышкин на открытии осенней сессии ГД, еще раз ярко продемонстрировали тот факт, что идея глобализации и создания однополярного мира утопична.

В условиях перехода к многополярному измерению, развития регионализации в противовес глобализации и формирования на нашем континенте евразийского полюса перед РФ стоят задачи пересмотра и корреляции существующих направлений как регионального, так и евразийского сотрудничества, развития новой многовекторной политики, нацеленной на формирование евразийских ценностей.

Сравнивая уровень межрегионального сотрудничества евроатлантических стран и стран евразийского полюса можно констатировать определенное отставание как в правовой, так и в социальной сферах.

В первую очередь хотелось бы остановиться на правовой cфepe, так как именно право регулирует исключительно все отношения как на национальном, так и на наднациональном уровне. Евроатлантические правовые комиссии, занимающиеся в настоящее время распространением европейских ценностей, функционируют не только в Европе (Венецианская Комиссия и Комиссия по совершенствованию правосудия - СЕПЕШ Совета Европы), а также и в Америке (Центр изучения правосудия обеих Америк, Межамериканский юридический комитет). Их деятельность охватывает как европейские страны, так и ряд стран Азии, Африки, Евразии и Америки. Активно функционирует ЕСПЧ и аналогичные региональные суды (Межамериканский суд по правам человека (Межамериканская демократическая хартия)) (Африканский суд справедливости и прав человека).

Социальная сфера затрагивает как нации в целом, так и каждого человека в частности, и достижение взаимопонимания в социальной сфере должно быть целью всех стран. Несмотря на постоянную критику со стороны запада за поддержку Россией русскоязычного населения и пространства в сфере социальной интеграции, в создании социальных, в том числе языковых пространств активно функционируют такие западные организации, как Франкофония (французский язык), Содружество наций (английский), Содружество португалоязычных стран (португальский), Ибероамериканское сообщество (испанский), Нидерландский языковой союз и т.д. При них функционируют такие правовые организации как ассоциации конституционных судов, использующих 
DOI: $10.7256 / 1811-9018.2014 .12 .14003$

При цитировании этой статьи сноска на dоі обязательна

\section{Право и политика $12(180) \cdot 2014$}

французский язык, Конференция конституционных судов португалоязычных стран, Иберо-американская конференция по конституционному правосудию, Суды Содружества наций, Конференция европейских конституционных судов, уделяющие немало времени пропаганде европейских ценностей.

И это в ситуации полного отсутствия аналогичных структур не только в Евразии, но и в Азии, хотя РФ участвует в Азии в деятельности таких авторитетных организаций как Организация Азиатского диалога, Азиатская парламентская ассамблея, Азиатско-Тихоокеанский парламентский форум, Парламентская ассамблея ОИК и т.д.

Отдельное место в организации и налаживании диалога занимает межпарламентское сотрудничество. О его актуальности было отмечено в выступлении Путина В.В. на расширенном заседании Совета глав государств-членов ШОС 12 сентября 2014 года в Душанбе. Активное участие в межпарламентских ассамблеях и межрегиональных форумах могло бы обеспечить парламентариям прямой доступ к общественности и возможность доводить напрямую до сведения парламентариев и населения различных стран информацию об острых вопросах... способствуя преодолению кризиса доверия в мире.

Европейские парламентские организации активно работают в рамках таких межпарламентских ассамблей, как Европейско-Латиноамериканская парламентская ассамблея и Парламентская ассамблея Африканского, Карибского, Тихоокеанского регионов, включающие как европейский парламент, так и парламенты стран и региональных объеди- нений Латинской Америки, Африки и Карибского бассейна. Известны межрегиональные форумы США - Африка, ЕвропаАзия, США-АСЕАН и т.д. Все эти организации позволяют активно действовать в мировом пространстве, предоставляя мировой общественности соответствующую информацию в выгодном им ракурсе. Важно активизировать участие евразийских парламентариев и использовать возможности межпарламентского сотрудничества для решения существующих проблем и избежания возникновения их в будущем.

\section{Итоги}

О необходимости иначе взглянуть на мировую систему координат заявил и Председатель Правительства РФ Дмитрий Медведев, подводя итоги инвестиционного форума «Сочи-2014».

В целях восстановления взаимного доверия, конечно же, необходимо продолжать сотрудничество и диалог с региональными организациями Европы, и в то же время надо активизировать деятельность по созданию всех необходимых институциональных механизмов, межпарламентских ассамблей, правовых организаций, судов по правам человека (Евразийская хартия прав человека) и т.д. на евразийских и азиатских площадках и развивать сотрудничество с регионами, где мы сегодня слабо представлены, что, несомненно, будет способствовать продвижению и пропаганде в мире общеевразийских ценностей; повышению роли евразийского полюса и права на мировой арене, созданию условий для равноправного диалога между всеми участниками.

\section{Библиография:}

1. Balassa B. The theory of economic integration. London, 1962

2. Bjorn Hettne. Globalization and the New Regionalism: The Second Great Transformation. // Globalism and the New Regionalism. International Political Economy Series. / Edited by Björn Hettne, András Inotai and Osvaldo Sunkel. Palgrave Macmillan, March 1999.

3. Cappelletti M., Seccombe M., Weiler J. Integration through law: Europe and the American federal experience (3 vols.). New York: De Gruyter, 1986. Vol. 1. Book 1. P. 4.

4. Joram Mukama Biswaro. The Quest for Regional Integration in Africa, Latin America and Beyond in the Twenty First Century: Experience, Progress and Prospects. - Brasilia, 2011.

5. S. Weatherill. Law and Integration in the European Union. Oxford, 1996

6. Weber M. The Theory of Social and Economic Organisation. Free Press, 1997.

7. Гумилев Л.Н. Этно-ландшафтные регионы Евразии за исторический период. - В кн.: «Доклады на ежегодных чтениях памяти Л.С. Берга», XIII - XIV, Л., 1968.

8. Захаров В.М. Евразийский проект: Россия остается лидером военно-политической интеграции на постсоветском пространстве // Национальная оборона. 2012. № 5.

9. Лапин Н.И. Новые проблемы исследований региональных сообществ // Социологические исследования. 2010. №7

10. Лукашук И.И. Глобализация, государство, право, ХХІ век. М., 2000.

11. Оппенгейм Л.М. Международное право. М.: Позис. 2000.

12. Путин В.В. Новый интеграционный проект для Евразии - будущее, которое рождается сегодня // В.В. Путин. Известия. 03.10.2012.

13. Степин В.С. Цивилизация и культура. - СПб. : СПбГУП, 2011

14. Усенко Е. Т. Интеграция как всемирно-исторический процесс и международное право // Московский журнал международного права. 1992. № 1.

15. Шерьязданова К.Г. Современные интеграционные процессы. - Астана: Академия государственного управления при Президенте Республики Казахстан, 2010

\section{References (transliterated):}

1. Balassa B. The theory of economic integration. London, 1962

2. Bjorn Hettne. Globalization and the New Regionalism: The Second Great Transformation. // Globalism and the New Regionalism. International Political Economy Series. / Edited by Björn Hettne, András Inotai and Osvaldo Sunkel. Palgrave Macmillan, March 1999. 
DOI: $10.7256 / 1811-9018.2014 .12 .14003$

При цитировании этой статьи сноска на доі обязательна

Интеграционное право и наднациональные организации

3. Cappelletti M., Seccombe M., Weiler J. Integration through law: Europe and the American federal experience (3 vols.). New York: De Gruyter, 1986. Vol. 1. Book 1. P. 4.

4. Joram Mukama Biswaro. The Quest for Regional Integration in Africa, Latin America and Beyond in the Twenty First Century: Experience, Progress and Prospects. - Brasilia, 2011.

5. S. Weatherill. Law and Integration in the European Union. Oxford, 1996

6. Weber M. The Theory of Social and Economic Organisation. Free Press, 1997.

7. Gumilev L.N. Etno-landshaftnye regiony Evrazii za istoricheskii period. - V kn.: «Doklady na ezhegodnykh chteniyakh pamyati L.S. Berga», XIII - XIV, L., 1968.

8. Zakharov V.M. Evraziiskii proekt: Rossiya ostaetsya liderom voenno-politicheskoi integratsii na postsovetskom prostranstve // Natsional'naya oborona. 2012. № 5.

9. Lapin N.I. Novye problemy issledovanii regional'nykh soobshchestv // Sotsiologicheskie issledovaniya. 2010. №7

10. Lukashuk I.I. Globalizatsiya, gosudarstvo, pravo, XXI vek. M., 2000.

11. Oppengeim L.M. Mezhdunarodnoe pravo. M.: Pozis. 2000.

12. Putin V.V. Novyi integratsionnyi proekt dlya Evrazii - budushchee, kotoroe rozhdaetsya segodnya// V.V. Putin. Izvestiya. 03.10.2012.

13. Stepin V.S. Tsivilizatsiya i kul'tura. - SPb. : SPbGUP, 2011

14. Usenko E. T. Integratsiya kak vsemirno-istoricheskii protsess i mezhdunarodnoe pravo // Moskovskii zhurnal mezhdunarodnogo prava. 1992. № 1.

15. Sher'yazdanova K.G. Sovremennye integratsionnye protsessy. - Astana: Akademiya gosudarstvennogo upravleniya pri Prezidente Respubliki Kazakhstan, 2010 